\title{
Love in the time of Covid-19: a case-study of the complex laws governing weddings
}

\author{
Rebecca Probert ${ }^{1 \star}$ (D) and Stephanie Pywell ${ }^{2 \dagger}$ \\ ${ }^{1}$ University of Exeter, Exeter, UK and ${ }^{2}$ The Open University, Milton Keynes, UK \\ *Corresponding author e-mail: R.J.Probert@exeter.ac.uk
}

(Accepted 4 March 2021)

\begin{abstract}
During 2020, weddings were profoundly affected by the Covid-19 pandemic. During periods of lockdown few weddings could take place, and even afterwards restrictions on how they could be celebrated remained. To investigate the impact of such restrictions, we carried out a survey of those whose plans to marry in England and Wales had been affected by Covid-19. The 1,449 responses we received illustrated that the ease and speed with which couples had been able to marry, and sometimes whether they had been able to marry at all, had depended not merely on the national restrictions in place but on their chosen route into marriage. This highlights the complexity and antiquity of marriage law and reinforces the need for reform. The restrictions on weddings taking place also revealed the extent to which couples valued getting married as opposed to having a wedding. Understanding both the social and the legal dimension of weddings is important in informing recommendations as to how the law should be changed in the future, not merely to deal with similar crises but also to ensure that the general law is fit for purpose in the twenty-first century.
\end{abstract}

Keywords: family law; marriage law; weddings; Covid-19

\section{Introduction}

Weddings, like so many other aspects of life, have been profoundly affected by the Covid-19 pandemic. For the months of lockdown, the vast majority of weddings were effectively prevented from taking place at all, and in August 2020 the Office for National Statistics estimated that this would have resulted in 73,400 weddings in England having to be postponed. ${ }^{1}$ Even once lockdown was eased, ${ }^{2}$

\footnotetext{
${ }^{\dagger}$ The authors would like to acknowledge the couples who acted as pilot-testers, all of those who took the time to respond to our survey, and Guides for Brides, Bridebook, Rock My Wedding, The Secret Barrister, We Talk Weddings, Love My Dress ${ }^{\star}$ Wedding Blog, Occasion Queens, Netmums and Mumsnet for promoting the survey. We would also like to thank the moderators of all the closed Facebook groups who allowed the second author to become a member so that she could publicise the research to brides- and grooms-to-be.

${ }^{1}$ Office of National Statistics Coronavirus (Covid-19) roundup: People and social impacts 21 August 2020 https://www.ons. gov.uk/peoplepopulationandcommunity/healthandsocialcare/conditionsanddiseases/articles/coronaviruscovid19rounduppeopleandsocialimpacts/2020-07-03\#wedding (last accessed 17 March 2021). Although the estimate is based on previous years' figures for England and Wales, the source clearly states that the figure of 73,400 refers to England; no comparable figure was calculated for Wales because of the different end dates for lockdown (personal email from ONS to the second author, 2 September 2020). Starting from monthly, rather than daily, data tables for both countries, and making some minor assumptions relating to their different end dates, we arrived at a total of 73,432.

${ }^{2}$ The Health Protection (Coronavirus Restrictions) (Wales) (Amendment) (No 6) Regulations 2020, WSI 2020/619 (W 141) enabled weddings to go ahead in places of worship and register offices in Wales from 12.01am on 22 June 2020. Couples in England had to wait until 4 July: Health Protection (Coronavirus Restrictions) (No 2) (England) Regulations 2020, SI 2020/684.

( $\odot$ The Author(s), 2021. Published by Cambridge University Press on behalf of The Society of Legal Scholars. This is an Open Access article, distributed under the terms of the Creative Commons Attribution licence (https://creativecommons.org/licenses/by/4.0/), which permits unrestricted re-use, distribution, and reproduction in any medium, provided the original work is properly cited.
} 
restrictions on weddings continued for some time. As a result, many more couples who were planning to marry in the second half of 2020 will also have deferred getting married, either because of their uncertainty as to whether they would be able to do so on their intended date, or because of their certainty that they would not be able to have the ceremony they wanted.

Despite popular references to a 'ban' on weddings, ${ }^{3}$ it should be noted that there was never any specific prohibition on weddings as such. Confusion on this point may have been created by Boris Johnson's mention of weddings in his announcement on 23 March when he declared that the Government would 'stop all social events, including weddings, baptisms and other ceremonies'. This, however, was intended as an example of the impact of the wider measures being proposed rather than indicating a specific ban. Those wider measures did effectively make it impossible for most weddings to go ahead. Places of worship were required to close except when conducting funerals or broadcasting an act of worship. ${ }^{5}$ Many approved premises - venues such as hotels and stately homes where marriages can take place - were also required to close as a result of the pandemic. ${ }^{6}$ And the restrictions on movement ${ }^{7}$ and on gatherings of more than two people ${ }^{8}$ posed an obvious obstacle to ceremonies taking place, even if the number attending were reduced to the legal minimum.

A few weddings, however, were able to take place both before and during lockdown. ${ }^{9}$ The fact that this was easier for some than for others highlighted some of the long-standing anomalies within the laws governing marriage. As the Law Commission has pointed out in its recent consultation paper, these laws are 'an ancient and complex hodgepodge of different rules for different types of ceremonies', ${ }^{10}$ preventing many couples from celebrating their entry into marriage in a form that is meaningful to them. The circumstances of Covid-19 meant that the impact of even minor legal differences became magnified, and sometimes determined whether couples could marry at all. The difficulties that many couples faced in marrying after lockdown further served to illustrate the complexity and antiquity of marriage law. The ease or speed with which couples could marry - and the cost of doing so - depended not merely on the national restrictions in place, or even on local conditions, but on their chosen route into marriage.

The restrictions on weddings taking place also revealed the extent to which couples valued getting married as opposed to having a wedding. There is, of course, a vast body of scholarship on why and how couples get married, ${ }^{11}$ as well as on what couples do if they have no way of formalising their relationship, ${ }^{12}$ and on how not all options for getting married are available to all couples. ${ }^{13}$ But in practice most couples have not previously had to choose between marriage as a change of legal (and potentially

\footnotetext{
${ }^{3}$ See eg R Jones 'Cancelled weddings - refusal to issue refund may be breach of law'(The Guardian, 26 May 2020).

${ }^{4}$ See https://www.gov.uk/government/speeches/pm-address-to-the-nation-on-coronavirus-23-march-2020, (last accessed 17 March 2021).

${ }^{5}$ The Health Protection (Coronavirus, Restrictions) (England) Regulations 2020, SI 2020/350, reg 5(5) and (6).

${ }^{6}$ The Health Protection (Coronavirus, Business Closure) (England) Regulations 2020, SI 2020/327; The Health Protection (Coronavirus, Restrictions) (England) Regulations 2020, SI 2020/350, reg 5(3).

${ }^{7}$ The Health Protection (Coronavirus, Restrictions) (England) Regulations 2020, SI 2020/350, reg 6(1).

${ }^{8}$ The Health Protection (Coronavirus, Restrictions) (England) Regulations 2020, SI 2020/350, reg 7.

9'Coronavirus: Couple married on Anglesey with no guests', 24 March 2020, https://www.bbc.co.uk/news/uk-wales52018518; 'Joe and Alana said "I do" with two hours' notice before lockdown!' (Stoke Sentinel, 4 April 2020), https:// www.stokesentinel.co.uk/news/local-news/joe-alana-said-i-do-4009565 (both last accessed 17 March 2021).

${ }^{10}$ Law Commission Getting Married: A Consultation Paper on Weddings Law, CP 247 (3 September 2020) para 1.33.

${ }^{11}$ See eg J Eekelaar and M Maclean 'Marriage and the moral bases of personal relationships' (2004) 31 Journal of Law and Society 510; see also J Eekelaar 'Why people marry: the many faces of an institution' (2007) 41 Family Law Quarterly 413; RC Akhtar et al (eds) Cohabitation and Religious Marriage: Status, Similarities and Solutions (Bristol: Bristol University Press, 2020).

${ }^{12}$ The focus of the literature here has tended to be on same-sex civil partnerships: see eg B Shipman and C Smart "It's made a huge difference": recognition, rights and the personal significance of civil partnership' (2007) 12(1) Sociological Research Online.

${ }^{13}$ The focus here has been on the limited options for same-sex couples to marry in a religious ceremony: see eg PW Edge and D Corrywright 'Including religion: reflections on legal, religious, and social implications of the developing ceremonial law of marriage and civil partnership' (2011) 26(1) Journal of Contemporary Religion 19; P Johnson and RM Vanderbeck 'Sacred spaces, sacred words: religion and same-sex marriage in England and Wales' (2017) 44(2) Journal of Law and Society 228.
} 
social) status, as a public declaration by a couple of their love for each other, and as a celebration with family, friends, and the wider community, marked by the religious rites or social rituals of their choosing. ${ }^{14}$ In 2020, however, tens of thousands of couples were forced to choose between the legal and the celebratory aspects of marriage.

Our aim in this paper is not to delve into the minutiae of the specific (and frequently changing) regulations and guidance about when weddings could take place in 2020, but rather to explore these broader issues about the legal regulation of marriage and its meaning to couples today, as brought into stark relief by the pandemic. In order to do so, we draw on the findings of a survey that we carried out in the summer of 2020. This focused on couples whose plans to marry in England and Wales had been affected by Covid-19, whether they had married earlier than they had planned, had been unable to marry during lockdown, had altered or postponed their post-lockdown ceremonies, or decided to marry because of the pandemic. ${ }^{15}$ In total we received 1,449 responses, each answering between two and 16 questions. ${ }^{16}$ Almost half of the respondents also availed themselves of the opportunity to vent their feelings by answering an open question at the end of the survey inviting them to include anything else that they wanted to say about how Covid-19 had affected their wedding plans. Over 45,000 words of text were generated by this last question alone, providing particularly rich insights into respondents' feelings about getting married and their perceptions of the law.

Understanding both the social and the legal dimension of marriages is important in informing recommendations as to how the law should be changed in the future, not merely to deal with similar crises but also to ensure that the general law of marriage is fit for purpose in the twenty-first century. In the final section we turn to this issue and consider the implications of our findings for the provisional proposals for reform set out in the Law Commission's consultation paper on weddings law, which was published in September 2020. ${ }^{17}$ The Commission's project on reforms to weddings law had begun in July 2019, having been preceded by a scoping paper in $2015 .^{18}$ Its aim was to 'provide recommendations for a reformed law of weddings that allows for greater choice within a simple, fair and consistent legal structure'. ${ }^{19}$ The resulting Consultation Paper, the majority of which was drafted before the public health emergency, ${ }^{20}$ proposed replacing the current regime - which consists of a confused mix of buildings-based regulation and specific rules for religious groups - with a system of regulation focusing on an officiant. Publication of the Consultation Paper was delayed because of the pandemic, enabling the Commission to include consideration of what further measures might need to be put in place during any future crisis. Our focus here will be on how our empirical evidence underlines the need for both general reform and specific measures to ensure that it is always possible for marriages to take place in some form.

Before exploring our findings, however, we will describe how the data was gathered, and discuss the validity of our sample.

\section{Gathering the data}

Our focus on those who had been planning to marry in England and Wales was intended to align with the Law Commission's Weddings project. ${ }^{21}$ As the affected population was geographically dispersed,

\footnotetext{
${ }^{14}$ On the way in which marriage combines these different elements see eg R Auchmuty 'Same-sex marriage revived: feminist critique and legal strategy' (2004) 14 Feminism \& Psychology 101 at 102; JA Nichols 'Introduction' in JA Nichols (ed) Marriage and Divorce in a Multicultural Context (Cambridge: Cambridge University Press, 2012) p 2; W Leeds-Hurwitz Wedding as Text: Communicating Cultural Identities Through Ritual (Mahwah: Lawrence Erlbaum Associates, 2002).

${ }^{15}$ These were the categories that we identified in our call for participants; see further below for explanation of how it was disseminated.

${ }^{16}$ The number varied because of skip logic.

${ }^{17}$ Law Commission, above $\mathrm{n}$ 10. The first author is the specialist consultant on this project but is writing here in a personal capacity.

${ }^{18}$ Law Commission, Getting Married: A Scoping Paper (17 December 2015).

${ }^{19}$ See https://www.lawcom.gov.uk/project/weddings/ (last accessed 17 March 2021).

${ }^{20}$ Law Commission, above n 10, p 2.

${ }^{21}$ The survey therefore excluded civil partnerships. We received five emailed enquiries about these, each of whom received a personal response explaining the rationale for the exclusion of this type of ceremony. In addition, since our aim was to
} 
and we had no practicable means of identifying all its members, we decided to employ convenience sampling, and promote the survey on social media. In addition to putting out calls on Facebook and Twitter, ${ }^{22}$ we were given approval to use our existing contacts, some of whom are in wedding-related professions, and to approach the gatekeepers of some websites and Facebook groups for brides- and grooms-to-be. These more targeted approaches added an element of purposive sampling, and the latter in particular proved extremely fruitful: we received hundreds of responses in 24 hours when the moderators of some of the Facebook groups posted messages in their own right.

The survey was open between 30 July and 31 August 2020. During this time the guidance about wedding receptions changed again, ${ }^{23}$ but while this undoubtedly added to the sense of uncertainty articulated by our respondents it did not directly affect any of the questions we asked. Calculated as a percentage of the total number of couples affected, ${ }^{24}$ the 1,449 usable responses ${ }^{25}$ we received would represent a very small response rate. ${ }^{26}$ Absolute sample size is, however, more important than relative sample size, and even 1,000 individuals would be regarded as a valid sample for the whole population of the UK. ${ }^{27}$ YouGov, for example, usually has samples of 1,500 or 2,000 respondents. ${ }^{28}$ Our data can therefore be regarded as constituting a statistically valid sample.

It is also safe to assume that our sample is reasonably representative of those who would have married in 2020. While those aged over 45 are less likely to use the internet for social messaging than those in younger age groups, and so may have been less likely to see and respond to our survey, the percentage of marriages within this group is also lower. ${ }^{29}$ The responses as to how couples were planning to marry closely matched national-level statistics on how couples have married in recent years, with

assess the impact of the different legal requirements on whether weddings went ahead or not, we did not invite responses from couples who had been planning to have a non-legally recognised ceremony, nor did we ask those who had had to postpone their legal wedding whether they had had a non-legally-recognised ceremony instead. Such ceremonies form the subject of a separate project on which the first author is a co-investigator: see https://www.nuffieldfoundation.org/project/weddingnot-marriage-exploring-non-legally-binding-ceremonies (last accessed 17 March 2021).

${ }^{22}$ We obtained our institutions' ethics committees' approval to use our private and institutional Facebook and Twitter accounts, with requests that the information be shared widely because we knew anecdotally that couples with changed wedding plans knew others in the same position.

${ }^{23}$ In England, wedding receptions for up to 30 people, plus venue and third-party catering staff, were permitted with social distancing in Covid-19 secure venues from 15 August (Department for Business, Energy \& Industrial Strategy and Ministry of Housing, Communities \& Local Government Covid-19: Guidance for small marriages and civil partnerships updated 14 August 2020). In Wales, wedding receptions of up to 30 people were permitted indoors or outdoors from 22 August (Welsh Government, Guidance to local authorities, approved premises and places of worship on marriages and civil partnerships: coronavirus, updated 22 August 2020).

${ }^{24}$ Because of the way in which the survey was promoted we have no way of knowing how many saw it and so cannot calculate the response rate among those who did.

${ }^{25}$ We received a total of 1,531 completed responses, but had to delete 57 responses where the answer 'no' had been given to one of the consent questions, plus 25 responses where the couple had neither originally planned to marry in England or Wales, nor had any current plans to do so and so fell outside the parameters of our study.

${ }^{26}$ Based on the estimate that 73,432 weddings were postponed on account of lockdown, our 615 responses in this category represent a response rate of $0.84 \%$. A further 793 responses were received from those who had been planning to marry between July and December; based on ONS data, we calculated that a further 144,846 weddings would have taken place during this time, giving a response rate of $0.55 \%$. We also received 41 responses from couples who were in neither of these situations.

${ }^{27}$ A Bryman Social Research Methods (New York: Oxford University Press, $5^{\text {th }}$ edn, 2016) p 183.

${ }^{28}$ YouGov (2018) Research Q®As, https://yougov.co.uk/about/panel-methodology/research-qs/ (last accessed $17 \mathrm{March}$ 2021). See also R Mortimore 'Three frequently asked questions', noting that MORI polls usually involved 1,000 or 2,000 respondents to represent a population of (at the time he was writing) 42 million: https://www.ipsos.com/ipsos-mori/enuk/three-frequently-asked-questions (last accessed 17 March 2021).

${ }^{29}$ In 2017 13\% of those marrying were aged 45-54; within this group, $72 \%$ used the internet for social messaging: ONS (2020) Marriages in England and Wales, Table 3 Men and Table 4 Women, https://www.ons.gov.uk/peoplepopulationandcommunity/birthsdeathsandmarriages/marriagecohabitationandcivilpartnerships/datasets/marriagesinenglandandwales2013; ONS (2020) Internet access - households and individuals data, Table 6 Internet activities, by age group, sex and disability status https://www.ons.gov.uk/peoplepopulationandcommunity/householdcharacteristics/homeinternetandsocialmediausage/datasets/internetaccesshouseholdsandindividualsreferencetables (both accessed 29 March 2021). 
73.9\% reporting that they had originally planned to marry in a civil ceremony in a register office or on approved premises, ${ }^{30} 21.3 \%$ in an Anglican ceremony, $4.5 \%$ in a 'registered place of worship', and $0.2 \%$ according to Jewish usages. ${ }^{31}$

The responses to the survey demonstrated the impact not just of the pandemic but also the uncertainty engendered by the changing regulations on when weddings (and wedding receptions) could take place. Of our 1,449 respondents, 625 had been unable to marry on their intended wedding date as it fell during the period of lockdown: ${ }^{32}$ of these, 10 managed to bring the date forward and marry before the start of lockdown, while 615 ('the lockdown group') had to postpone their plans. A further 793 couples ('the post-lockdown group') had been planning to marry between the end of lockdown and the end of 2020 and had had to change their plans in some way, whether by changing the month, year, day of the week, or time of day of their wedding, or the venue, the type of wedding ceremony, or the number of guests. The remaining 31 had either been prompted to marry in England and Wales on account of Covid-19, ${ }^{33}$ or, more sadly, had decided to postpone their wedding indefinitely, were no longer planning to marry, or were unable to marry. ${ }^{34}$

It should be noted that our call for participants specifically invited responses from those whose plans to marry in England and Wales had been affected by Covid-19. It is thus of some significance that the ways in which the post-lockdown group had been planning to marry differed only marginally from those of the lockdown group. The only discernible difference was that the percentage reporting that they had originally been planning to marry in a register office was slightly lower among postlockdown group: $9.2 \%$ as compared to $12.0 \%$. This was only to be expected, as register office weddings are often smaller and so were less likely to be affected by the post-lockdown restrictions on numbers. However, even some of the post-lockdown group who had been planning to marry in a register office with just two witnesses reported that their plans had been disrupted, if only by needing to postpone their ceremonies. The conclusion is that the pandemic affected all types of weddings.

As the next section will show, however, the precise impact was different for different types of weddings.

\section{Navigating the complexities of marriage law}

The rules governing how and where couples can get married in England and Wales are not always easy to navigate even at the best of times. But the pandemic has served to highlight some of the more fundamental structural problems with those rules, and how they differ depending on whether the marriage is civil or religious, and, if the latter, whether it is Anglican, Jewish, Quaker, or conducted in a registered place of worship. The findings of our survey illustrated how couples' experiences were affected by the type of wedding that they were hoping to have. Here we will primarily be drawing on the qualitative evidence from the final open question, which respondents used to identify particular obstacles that they had faced, along with media reports of weddings during the period.

\footnotetext{
${ }^{30}$ In 2017 civil weddings accounted for $77 \%$ of the total, with $92 \%$ of such weddings being recorded on approved premises and 8\% in a register office (ONS Marriages in England and Wales: 2017 (14 April 2020) https://www.ons.gov.uk/peoplepopulationandcommunity/birthsdeathsandmarriages/marriagecohabitationandcivilpartnerships/bulletins/marriagesinenglandandwalesprovisional/latest\#type-of-ceremony (last accessed 17 March 2021)). In our sample $90 \%$ indicated that the wedding was to take place on approved premises as compared to $10 \%$ in a register office.

${ }^{31}$ Numbers do not add to $100 \%$ because of rounding. The term 'registered place of worship' is explained further below.

${ }^{32}$ Since the end date of lockdown for these purposes differed between England and Wales, we had an initial question that separated the two. Overall, 1,382 couples had originally planned to marry in England, and 60 in Wales.

${ }^{33}$ Of these seven couples, three had previously intended to marry overseas; two wanted the legal and financial security of being married, one wanted to start a family, and one wanted to 'make more of a commitment to each other having spent so long together and getting on very well'.

${ }^{34}$ Those couples who indicated that they were no longer planning to marry were not asked any further specific questions because of the potential sensitivities of the reasons underlying this decision. They were, however, given the option of answering the open question at the end. Two of the 21 who said that they had postponed their weddings 'indefinitely' did note their plans to marry on specific dates, and one of the two couples who said they were no longer able to marry explained that it was because the venue had permanently closed as a result of the pandemic.
} 


\section{(a) Whether couples are limited to marrying in a particular parish or district}

The first consideration for many couples will be where their wedding takes place, and it is therefore convenient to consider these rules first as they in turn may affect the preliminaries that will need to be completed. ${ }^{35}$ Couples marrying in a civil ceremony can do so in any register office or at approved premises in England and Wales, and are not limited to marrying in the registration district in which either or both of them live. ${ }^{36}$ Quaker and Jewish marriages are similarly unlimited as to location. Those marrying in a registered place of worship - that is, a building where any religious group habitually worships that has been specifically registered as a place where weddings can be solemnised are generally limited to buildings located in the district where they live, although provision is also made for them to marry in the nearest such place if there is none in the district, or for them to marry in their usual place of worship. ${ }^{37}$ Those wishing to marry in an Anglican church, however, must either live in the parish, be regular worshippers at that church, or establish a 'qualifying connection'. ${ }^{38}$ There are various ways to establish such a connection, but where the couple have no preexisting link with the church the only option is to attend services there for not less than six months. ${ }^{39}$

Those hoping to marry in a particular Anglican church by attending services there were particularly affected by the lockdown. As one noted, 'services are being hosted online which doesn't count towards us making a connection'. Another reported ' 6 weeks of panic' and being told that they would not be able to marry in the church as they did not qualify. A third had been halfway through their required number of attendances when the church was closed; the result was that they did not have time to establish a connection and have the banns read in time for their planned summer wedding, and opted for a civil ceremony instead, 'with a church blessing service next spring if restrictions allow'.

\section{(b) The preliminaries required before a wedding can go ahead}

No wedding can take place until certain preliminary formalities have been completed. For couples who are planning to marry in an Anglican church, the most common form of preliminaries is banns, which must generally ${ }^{40}$ be read aloud in the church(es) in the parish(es) where they live - and (if different) the church in which they intend to marry - on three Sundays before the wedding. ${ }^{41}$ Those marrying in any secular or religious venue other than an Anglican church must give formal notice of their intention to marry at the registration office for the district(s) in which they live. ${ }^{42}$ Printed or electronic notices must then be displayed for a minimum period of 28 days. If, during that period, no one objects to the proposed wedding, the couple are issued with a superintendent registrar's certificate that is valid for one year.

Our findings highlighted the inflexibility of these preliminaries, and showed how the differences between Anglican and civil preliminaries could be either an advantage or a disadvantage at different times during the pandemic. A significant advantage for those marrying in an Anglican church is that there are two alternative preliminaries to banns. Any couple can apply for a common licence from the Diocesan Registrar who covers the parish where they intend to marry; this requires the production of

\footnotetext{
${ }^{35}$ The preliminaries will be discussed in the next sub-section.

${ }^{36}$ Marriage Act 1949, s 35(2A) and (2B).

${ }^{37}$ Marriage Act 1949, ss 34, 35(1) and (2).

${ }^{38}$ Marriage Act 1949, s 6; Church of England Marriage Measure 2008, s 1(1) and (10); Marriage (Wales) Act 2010, s 2(1) and (10).

${ }^{39}$ Church of England Marriage Measure 2008, s 1(3); Marriage (Wales) Act 2010, s 2. The other ways of establishing a qualifying connection are being baptised in the parish, being entered in the register book of confirmation, having lived in the parish for six months at some point, a parent having lived in the parish for six months or having habitually attended public worship there for that period, or a parent or grandparent having married there.

${ }^{40}$ The rules on the calling of banns are particularly complicated, with numerous rules making provision for different eventualities: for an overview see Law Commission, above n 10, paras 2.70-2.78.

${ }^{41}$ Marriage Act 1949, s 6.

${ }^{42}$ Marriage Act 1949, s 27(1).
} 
some documents and a personal meeting. In certain circumstances, some couples can obtain a special licence from the Archbishop of Canterbury. In the period immediately before lockdown, the speed with which either type of licence could be obtained was a distinct advantage. Of the 10 respondents who had brought their weddings forward to ensure that they could get married before lockdown, six were able to do so because their notices of marriage had already been displayed for the requisite period or their banns had already been called. Of the four who obtained authorisation to marry quickly, one had obtained a Registrar General's licence, which, since it is limited to cases in which a person is seriously ill and not expected to recover, indicated a particularly tragic reason for speed. ${ }^{43}$ The other three, however, were all marrying in Anglican churches by virtue of either a common or special licence. ${ }^{44}$ For any couple who had not already given notice of their intention to marry in a non-Anglican ceremony, there would have to have been a 29-day wait between doing so and the authority to marry being issued - a period that significantly exceeded anyone's inkling that the impending lockdown would be so comprehensive. ${ }^{45}$

During the period of lockdown, the differential provision for Anglican and other ceremonies became even more pronounced. The Church of England's Faculty Office, which is responsible for granting special licences on behalf of the Archbishop of Canterbury, rose to the occasion and did everything it could to facilitate marriages taking place where that could be achieved within the guidelines, or where an individual was terminally ill. It provided clear and helpful advice on its website, ${ }^{46}$ including telephone numbers for those involved in considering applications to be contacted directly, created a new online application form, ${ }^{47}$ and allowed copies of documents to be submitted electronically. As it subsequently noted, it issued 104 special licences between 23 March and 4 July 2020 alone in order to enable the marriages of those who were terminally ill, or who had a close family member who was terminally ill, whereas it would normally issue only 40 for this purpose in a whole year. ${ }^{48}$ Marriages conducted under the auspices of a special licence included that of a terminally ill man, who married in his garden, ${ }^{49}$ and a doctor and nurse who married in the chapel of the hospital where they worked. ${ }^{50}$ This latter marriage was possible within the terms of the regulations because those concerned were working together in a 'front-line' NHS hospital, and no one could begrudge such a couple getting married. But this should not obscure the fact that couples wishing to marry in a non-Anglican ceremony would not have had the option of doing so.

This is because a Registrar General's licence is far more limited in what it can authorise. The Registrar General must be satisfied that 'one of the persons to be married is seriously ill and not expected to recover and cannot be moved to a place at which under the provisions of the Marriage

\footnotetext{
${ }^{43}$ Marriage (Registrar General's Licence) Act 1970. A Registrar General's licence may be granted for any form of non-Anglican wedding. There is more information below about Registrar General's licences.

${ }^{44}$ One had obtained a common licence, one had obtained a special licence, and the third was unsure as to its name but said that the vicar had described it as an emergency licence.

${ }^{45}$ Marriage Act 1949, s 31(1)-(1A) requires all notices of marriage to be displayed in the register office for 28 days, beginning from the day after notice is entered in the marriage book or its online equivalent. There is a discretion to reduce the waiting period, but it requires an application to the Registrar General to be made showing that there are 'compelling reasons' for reducing the period 'because of the exceptional circumstances of the case' (s 31(5A)). It is also less well known than the options of applying for a common or special licence.

${ }^{46}$ See http://www.facultyoffice.org.uk/special-licences/marriage-law-news/ (last accessed 17 March 2021).

${ }^{47}$ Previously the relevant application form could be requested electronically and where the application related to a deathbed wedding the Faculty Office sent the form electronically as well (personal communication from Neil Turpin, Chief Clerk, Faculty Office of the Archbishop of Canterbury, 30 March 2020). The new online form streamlined this process.

${ }^{48}$ Faculty Office 'Response to Law Commission consultation on weddings law', 11 January 2021, pp 4-5, https://www.facultyoffice.org.uk/wp-content/uploads/2021/01/Getting-Married-Response-to-the-Consultation-Paper-on-Weddings-LawDecember-2020.pdf (last accessed 17 March 2021).

49“"Perfect day": Vicar gets special permission from Archbishop of Canterbury to wed couple in garden' (The Sun, 14 May 2020) https://www.thesun.co.uk/news/11622330/wedding-archbishop-canterbury-coronavirus/ (last accessed 17 March 2021).

${ }^{50}$ 'Doctor and nurse tie the knot in hospital chapel after wedding cancelled because of coronavirus' (Metro, 26 May 2020) https://metro.co.uk/2020/05/26/doctor-nurse-tie-knot-hospital-chapel-wedding-cancelled-coronavirus-12760970/ (last accessed 17 March 2021).
} 
Act 1949 the marriage could be solemnised'. ${ }^{51}$ A certificate from a registered medical practitioner will generally be necessary to establish that this condition is satisfied and that 'the person in respect of whom such conditions are satisfied is able to and does understand the nature and purport of the marriage ceremony. ${ }^{52}$ A newspaper report of marriages taking place by this route underlined that it was only available for those who were terminally ill. ${ }^{53}$

Those needing to marry by Registrar General's licence would also have had far more difficulty in tracking down the information explaining what they needed to do. Since applications for such licences are not made directly to the Registrar General, but rather to the superintendent registrar for the district in which the person seeking the licence is resident, individuals were dependent on the quality of information provided by their local authority. A survey of 169 websites conducted on 2 April 2020, shortly after lockdown had begun, found that the vast majority of local authorities were simply stating that they were not conducting wedding ceremonies because of Covid-19. A few made reference to the existence of special provisions for those who were ill, but only as part of their general advice rather than as a specific response to the crisis. ${ }^{54}$ Significantly, the number of marriages conducted on the basis of a Registrar General's licence was actually lower in the first three quarters of 2020 than it had been for the corresponding period in 2019: 375 as compared to $503 .^{55}$

As the period of lockdown drew to a close, those who were marrying in a civil ceremony, or non-Anglican religious ceremony, and had not completed the necessary preliminaries before lockdown, faced the worry of when they would be able to give notice. The closure of register offices throughout lockdown and beyond, and the lack of any option for giving notice remotely, ${ }^{56}$ meant that couples simply had to wait until they could get an appointment. One respondent had been planning to get married in England on 1 August 2020, almost a month after weddings were permitted to take place, but reported that they had had to postpone 'due to the council offices taking a long time, after lifts of lockdown'. Several others reported similar difficulties in giving notice, and one, a former registrar, expressed the hope that this would prompt the General Register Office and local government to 'digitise' and 'modernise' the 'archaic' registration services.

The lack of facilities for giving notice may be why even some couples who had been planning to marry in a register office with just two witnesses had to change the dates of their weddings. While this group was small (just eight respondents), half reported that they had had to postpone getting married to 2021, and one did not yet have a date for their rescheduled ceremony. Alternatively, it may have been that the register office no longer had capacity to conduct their wedding on the intended day and had to reschedule it. ${ }^{57}$

In other respects, it was couples who were marrying after Anglican preliminaries who were at something of a disadvantage, because the authority to marry is valid for a much shorter period. A couple

\footnotetext{
${ }^{51}$ Marriage (Registrar General's Licence) Act 1970, s 1(2).

${ }^{52}$ Ibid, s 3(d).

${ }^{53} \mathrm{~T}$ Earnshaw 'Three weddings have taken place in Kirklees during lockdown for very special reasons', 19 June 2020 , https://www.examinerlive.co.uk/news/west-yorkshire-news/three-weddings-taken-place-kirklees-18448667 (last accessed 17 March 2021). The report described them as taking place by 'special licence', but since they were conducted by registration officers they must have been authorised by a Registrar General's licence.

${ }^{54} \mathrm{R}$ Probert 'Love in a Covid-19 climate', Law and Religion UK, https://lawandreligionuk.com/2020/05/05/love-in-a-covid19-climate/ (last accessed 17 March 2021).

${ }^{55}$ ONS 'Number of marriages solemnized by a Registrar General's Licence by month, 2017 to 2020, England and Wales' (20 November 2020), https://www.ons.gov.uk/peoplepopulationandcommunity/birthsdeathsandmarriages/marriagecohabitationandcivilpartnerships/adhocs/12543marriagessolemnizedbyaregistrargeneralslicencebymonthenglandandwales 2017 to2020 (last accessed 17 March 2021).

${ }^{56}$ The law currently requires such notice to be given in person, and for each person giving notice to sign a declaration that there is no impediment to the marriage in the presence of a registration officer (Marriage Act 1949, s 28). Making provision for notice to be given remotely would therefore have required primary legislation, as well as careful thought about what measures might be needed to guard against sham and forced marriages.

${ }^{57}$ The pressures on registration services are discussed further below.
} 
have to marry within three months of the banns being called or of a common licence being granted. ${ }^{58}$ For those who had already had their banns called before lockdown, or obtained a common or special licence, the lapse of time between the start of lockdown and the opening up of places of worship for weddings meant that the authority to marry would inevitably have lapsed and that the couple would therefore need to go through the process again.

The Church of England advised clergy that this could lead to some couples requiring a common or special licence in order to marry on their planned date, but acknowledged that others might choose to postpone their weddings. ${ }^{59}$ One respondent said that the church had advised them as to the possibility of a common licence; this particular couple, however, also had to establish a qualifying connection by attending services at the church so would either have needed to obtain a special licence to obviate the need for such a connection or have established their connection before applying for a common licence. Perhaps understandably, they had chosen to postpone their wedding to August 2021. While the Church of England's guidance also advised that the statutory fees would not be payable if a couple decided to cancel their wedding, and must be refunded in full if they had already been paid, ${ }^{60}$ a number of couples did have to pay for the banns to be called again. The number reporting having done so was, however, considerably smaller than the number who had had to pay to give notice again in advance of a planned ceremony elsewhere. ${ }^{61}$

With a superintendent registrar's certificate being valid for a full year, those who had already given notice of their intention to marry in a non-Anglican ceremony should in principle have been able to marry as soon as the wedding could be rearranged after restrictions were lifted. Nonetheless, a common complaint among couples was that their notices had expired, or would have expired by the date of the rearranged wedding. This was to some degree a reflection of how the uncertainty as to when weddings would be able to take place had led couples to postpone by many months to when they assumed it would be possible to marry. It also reflected how far in advance many couples had given notice, indicating that this is not something that tends to be left to the last moment.

For those who were required to give notice again, a particular complaint was being required to pay to do so. There was a lack of consistency on this between local authorities, confirming earlier research on the extent to which the interpretation and application of other rules governing weddings differs between different authorities. ${ }^{62} \mathrm{~A}$ few respondents expressed their gratitude that their councils had decided not to charge them for a second set of notices, clearly aware that others had not been so lucky. One said that they had written to their local MP to question the legitimacy of being asked to pay again; the advice they received was that this was now not required, but, as they noted, 'there are a lot of conflicting messages out there and there doesn't seem to be any consistency in approach'. Others who had had to pay twice expressed their disappointment and sense of unfairness at being asked to pay again. In total, 203 respondents reported that the cost of the wedding had increased because there was a fee for reissuing their notices of intention to marry, ${ }^{63}$ and a number of others were still uncertain as to whether they would be required to pay again. The variability in practice between local authorities was further underlined by different sums mentioned; since the fee for giving notice is set by statute, it should have been no more than $£ 35$, or $£ 70$ for the couple. ${ }^{64}$ In some cases

\footnotetext{
${ }^{58}$ Marriage Act 1949, ss $12(2)$ and 16(3).

${ }^{59}$ The Church of England Covid-19 Advice for clergy conducting weddings v 5.1, 17 August 2020.

${ }^{60}$ Ibid.

${ }^{61}$ Of the 299 respondents who had been planning to marry in Anglican churches either during lockdown or later in 2020, 84 reported that the cost of their wedding had increased, and 20 of them explained that this was because they had had to pay to have the banns called again.

${ }^{62}$ S Pywell and R Probert 'Neither sacred nor profane: the permitted content of civil marriage ceremonies' (2018) Child and Family Law Quarterly 415.

${ }^{63}$ This was $56 \%$ of the 362 respondents who reported that the cost of their civil ceremony had increased, and $18 \%$ of the 1,109 who had been planning to marry in such a ceremony.

${ }^{64}$ This fee applies unless one or both are neither relevant nationals nor exempt from immigration control, in which case the fee is $£ 47$ per person.
} 
the couple may have misremembered the amount, or misunderstood what the fee was for, but in other cases a higher sum reported most likely reflected an additional fee. ${ }^{65}$

For those who were subject to immigration control, giving notice again was even more complicated. One pointed out that it would cause them a significant delay: as they were marrying someone who wasn't from the UK originally, 'giving notice can take up to 70 days for us'. ${ }^{66}$ Another particularly irate respondent complained that they had had 'little information or contact despite having to pay our local council over 800 pounds so far between original fees, notices, and change fees/new notices'; they also commented that they had been 'watching the chicanery of changing what the fees are and who they apply to on their coronavirus updates pages'.

A third, who was planning to marry in an Anglican church, noted that resubmitting their notice of marriage meant 'taking annual leave again for 8+ days to stay in our parish', with the cost of staying in a hotel being added to the cost of the notice. While they did not specify that this was because of immigration requirements, it is unlikely that they would have chosen this route had they been able to avail themselves of the Anglican preliminaries. ${ }^{67}$ The combination of facts suggests that they were not a 'relevant national' ${ }^{68}$ for the purposes of immigration law but were exempt from immigration control, ${ }^{69}$ and that they had qualified to marry in that particular church on a basis other than residence or it being their usual place of worship. ${ }^{70}$ In such circumstances, the only way in which they could marry in their chosen church was to live in the parish for seven days before giving notice. ${ }^{71}$ The case is a particularly complex example of the absurdities that can arise on account of the intersection of different rules passed at different times for different purposes. More broadly, it is difficult to see what purpose was served by this period of residence, or indeed by displaying this couple's notice of marriage in a district where they did not live. ${ }^{72}$

Many couples whose notices had not expired needed to get them amended because of a change as to the venue. A superintendent registrar's certificate authorises a wedding to go ahead only in a specified location, and the marriage is void if the parties knowingly and wilfully marry anywhere else. ${ }^{73} \mathrm{~A}$ significant number of couples had changed where they were planning to marry, either because their original venue was not available on their rearranged date (or, in some cases, no longer existed) or because it was unable to accommodate social distancing. This was the case for $12 \%$ of those marrying other than according to Anglican rites, all of whom would have been required to give notice. ${ }^{74}$

\footnotetext{
${ }^{65}$ One noted having to pay $£ 45$ each, which is the sum charged by some local authorities by adding a $£ 10$ booking fee to the fee for giving notice: see S Pywell ' $2+2=£ 127$, if you're lucky', Law Society Gazette, 3 March 2020.

${ }^{66}$ This was a reference to the fact that the usual waiting period of 28 days may be extended by the Secretary of State to 70 days where the marriage is being investigated as a potential sham: Marriage Act 1949, s 28H(9) and Sch 3A, para 3.

${ }^{67}$ If either of the couple is not a 'relevant national', they may not marry after banns or licence (Marriage Act 1949, s 5(3)) but must instead give notice at a register office.

${ }^{68} \mathrm{~A}$ relevant national would be a British citizen, EEA national or Swiss national: Immigration Act 2014, s 62(1).

${ }^{69} \mathrm{~A}$ person who is not exempt from immigration control must give notice at a designated register office rather than the one in their district of residence (Asylum and Immigration (Treatment of Claimants, etc) Act 2004, s 19). For the categories of persons who are exempt from immigration control, see the Proposed Marriages and Civil Partnerships (Meaning of Exempt Persons and Notice) Regulations 2015, SI 2015/122, reg 3.

${ }^{70}$ For information about the powers of a superintendent registrar to grant a certificate to authorise a marriage in such cases, see the Marriage Act 1949, ss 34 and 35(3). A superintendent registrar has no power to grant a certificate to authorise a marriage to go ahead in a particular district just because the parties have a qualifying connection there.

${ }^{71}$ Marriage Act 1949, s 34.

${ }^{72}$ It should be noted that the need to establish residence in this way would also apply to any couples wishing to marry in a registered place of worship outside their usual district of residence who were unable to bring themselves within one of the existing exemptions. There is no equivalent of the Anglican 'qualifying connection' to allow couples to marry in a registered place of worship that is the church they attended during childhood, or where their parents worship.

${ }^{73}$ Marriage Act 1949, s 49(e).

${ }^{74}$ This does not necessarily mean that $12 \%$ had to amend their notices, as some might not have given notice before their plans changed. Conversely, it is possible that some couples marrying in Anglican ceremonies would also have needed to give notice and so amend their notices of marriages if they were marrying in a different church, although fewer couples marrying in this way changed where they were planning to marry. Those using the Anglican preliminaries would also need to have
} 


\section{(c) Venues and essential officials}

The fact that weddings cannot generally take place outdoors ${ }^{75}$ was one of the reasons why restrictions on marriages taking place in England and Wales were lifted later than they were in Northern Ireland. ${ }^{76}$ There are indications that the ability to marry outdoors would have helped weddings to go ahead safely rather than being postponed. One respondent who had always been planning to marry outdoors happily reported that they had been lucky in being able to go ahead on their intended day, if not with all of their intended guests, and that guests had not been required to wear masks. Another had switched to an outdoor location at their original venue, which also meant that they did not have to change the notice of marriage. However, even some of those who had been going to have an outdoor wedding found that this could not necessarily go ahead as planned. ${ }^{77}$ One couple had booked their wedding at a venue where the 'approved premises' consisted of a pagoda in the garden. However, its small size meant that it was not possible for six people - the two registration officers, the couple, and their two witnesses - to stand under it while being the required two metres apart. The insistence that all six would have to be under the pagoda 'for it to be legal' is likely to strike couples as somewhat farcical at the best of times; in this case, it meant that the wedding had to take place in a room inside the main building, which would have put those attending at greater risk of transmission.

The need for two registration officials to be present at this ceremony highlighted another anomaly. While lockdown restrictions were still in place, an online petition asked for weddings to be able to go ahead with only five persons present - the couple, two witnesses, and the registrar. ${ }^{78}$ The signatories were perhaps not aware that this had different implications for different types of weddings. For Anglican, Jewish and Quaker weddings, and for some weddings in registered places of worship, it would simply have been a matter of amending the restrictions in the emergency regulations on the number of persons who could meet. But for civil weddings, and any weddings in registered places of worship that had to be conducted in the presence of a registrar, it would have been necessary to make amendments to primary legislation about how weddings are conducted.

These significantly different legal processes are needed to achieve similar outcomes because the requirements as to who needs to be present to conduct the ceremony, and who needs to be present in order to register it, differ depending on the type of wedding in issue. Anglican weddings are the most straightforward in this regard, being conducted and registered by the same person. ${ }^{79}$ Jewish and Quaker weddings are more complex, but the statute does not specifically require weddings conducted according to such usages to be solemnised in the presence of any person, the focus of regulation being on who is responsible for registering the marriage. ${ }^{80}$ This designated person

banns called again, or obtain a new licence, if they were marrying in a different church from the one they had originally intended.

${ }^{75}$ The only weddings that are not limited to taking place in a particular building or room are Jewish and Quaker weddings, and Anglican weddings authorised by a special licence, although in practice Quakers marry in their meeting houses and the Faculty Office would not grant a special licence simply to authorise an outdoor wedding. However, a 'room' on approved premises is defined broadly enough to include outside structures: Marriage and Civil Partnerships (Approved Premises) Regulations 2005, SI 2005/3168, reg 2(1).

${ }^{76}$ Outdoor weddings and civil partnership ceremonies were allowed to go ahead in Northern Ireland from 8 June (The Health Protection (Coronavirus, Restrictions) (Amendment No 5) Regulations (Northern Ireland) 2020, SR 2020/96); 'Coronavirus: NI aims to allow small outdoor weddings from June', 28 May https://www.bbc.co.uk/news/uk-northern-ireland52809997; D Pocklington 'Outdoor weddings in Northern Ireland', Law and Religion UK, 9 June 2020, https://www. lawandreligionuk.com/2020/06/09/outdoor-weddings-in-northern-ireland/\#more-58564 (both last accessed 17 March 2021).

${ }^{77}$ Two who had planned outdoor weddings were no longer able to have them because had rescheduled their them to the winter months when these structures were not available.

${ }^{78}$ See https://petition.parliament.uk/petitions/315627.

${ }^{79}$ Both the Marriage Act 1949 and the Church of England's canons refer to marriages being conducted by a minister or clerk in Holy Orders: Canons of the Church of England, Canon B35(4), available at https://www.churchofengland.org/more/ policy-and-thinking/canons-church-england/section-b\#b44 (last accessed 17 March 2021). The person who conducts the wedding is responsible for registering it: Marriage Act 1949, s 53(a).

${ }^{80}$ This is the registering officer in the case of Quaker marriages or the secretary of the synagogue to which one of the parties belongs in the case of Jewish marriages: Marriage Act 1949, s 53. 
is simply required to satisfy themselves that the wedding was conducted according to Quaker or Jewish usages before registering it. ${ }^{81}$ Weddings in registered places of worship need only be solemnised in the presence of an authorised person; if no such person is present, they will need to be conducted in the presence of a civil registrar, who will usually be there in addition to the minister, priest or imam conducting the wedding. ${ }^{82}$ All civil weddings require the presence of both a superintendent registrar and a registrar. $^{83}$

While none of the respondents to the survey drew attention to this specifically - probably because none was aware of it - a number did identify the difficulties that they had experienced in booking (or rebooking) a ceremony with a registrar, in the light of the backlog of ceremonies that councils were dealing with. It is likely that this backlog could have been dealt with more quickly had it not been necessary for two registration officials to attend every civil wedding. One commented that their county council was 'still not letting new couples book a ceremony despite it now being over 2 months since ceremonies were allowed'. Another, whose wedding had not been able to go ahead in late June, said that they 'were made to feel like an inconvenience and not allowed to rebook until September'. Others reported the stress and sadness of waiting to see if they could book a ceremony, while one reported that it was 'still not possible to book a wedding that will take place this year in our county'.

\section{Getting married and having a wedding}

That the individuals who responded to the survey attached considerable importance to their weddings, and wanted to express their unhappiness about the way in which their plans had been affected, is understandable. What needs to be understood in formulating policy for emergencies is why their wedding was important to them. Our focus here is not on why they had decided to get married at all, or on the details of what they had planned for their wedding, but rather to highlight how the impact of the restrictions differed depending on whether the couple's main desire was to get married or to have a wedding.

For a small number of respondents, the wedding was important as a beginning. A few said that they would not live together without being married. One had brought their wedding forward (with the aid of a common licence) to ensure that they would not be separated during lockdown. Another reported sadly that 'having to postpone our wedding a year has meant another year apart from each other'; for them, being married in the presence of their loved ones was just as important as getting married, and the 30-person limit on attendees would have required them to select only a few people from their large family. A third expressed their 'shock that it was illegal to get married in England with no provision for even the smallest ceremony with the legal number of witnesses' and was clear that '[f]or us this is the most significant change in our life and we honour God by marrying. I didn't want to have my ceremony filmed I didn't mind that other people wouldn't have been able to make it, I just wanted to get married'.

A few more respondents said that they wanted to be married before starting a family. One of those who had not previously been planning to marry in 2020 had used the pandemic as the excuse for the 'small and intimate wedding' that both had wanted all along. Another, who was pregnant but had become unable to marry when planned, commented that 'due to the coronavirus our baby will now be born out of wedlock'. Others said that their plans for starting a family were on hold, with many adding that this was taking a toll on them in terms of the stress, anxiety, and emotional impact.

For some, the reasons for wanting to marry were legal, rather than religious or personal. These respondents were not necessarily marrying for pragmatic reasons; ${ }^{84}$ rather, these external reasons determined the timing of their wedding. There were a few for whom the timing of their wedding was critical because of their immigration status. One simply referred to 'immigration reasons', adding

\footnotetext{
${ }^{81}$ Marriage Act 1949, s 55(1)(b).

${ }^{82}$ Marriage Act 1949, s 44(2).

${ }^{83}$ Marriage Act 1949, s 45(1).

${ }^{84}$ On which see Eekelaar and Maclean, above n 11, at 518.
} 
that they would have been happy to have married in any way possible. Others specifically noted that it was crucial for them to supply a marriage certificate as part of their visa application; as one put it, had they not been able to be married in time 'we could have been forced to be separated, pay costly appeals, and possibly have no way to be married until the pandemic ended'. ${ }^{85}$ And two respondents who had not previously been intending to marry explained that they had decided to do so because they wanted the legal and financial security of being married. For at least one of these couples, getting married had more significance for the end of their relationship than the beginning; they described it as 'essentially being done to make it easier for the other person or the kids if either of us die'.

Since these were all spontaneous responses to an open question at the end of the survey, any quantitative analysis based on these answers alone would be inappropriate. However, some indication of how many respondents valued simply getting married above how they married can be gleaned from a separate question about whether couples would have got married on their original date had various options been available. Two of these options were for a socially distanced wedding with only those who were legally required to be present in attendance: the first envisaged the wedding taking place indoors with any people from different households separated by screens, while the second suggested a wedding outdoors. The third option, inspired by various accounts of Zoom weddings and Channel 4's 'Hitched at Home', ${ }^{86}$ was for a wedding by video link with everyone, including the couple and officiant, attending remotely, and unlimited guests. The question was directed solely at those whose weddings had been postponed because of lockdown, and while none of the options were particularly popular, $20 \%$ of respondents would have considered at least one of them, and just under $8 \%$ would have considered any of them.

Many of those who would have considered such options fell into a further group that indicated a simple desire just to get married. This desire had clearly been sharpened by the uncertainty as to whether even this would be possible and by the ongoing question mark over receptions. One, who commented that options 'of getting married at home via online link, or witnesses/guests online, would have been helpful', was in an area that was under a local lockdown and did not know whether even their postponed wedding would be able to take place.

This group emphasised how they had changed, or were thinking of changing, their plans in order to be able to marry - even if this meant not having the wedding they wanted. As mentioned above, 10 couples had been able to bring their weddings forward, and had married before the start of lockdown. Others had married once lockdown had ended, but indicated that they had done so with a smaller number of guests and with other changes to the ceremony. Many more had not yet married but explained how they had adapted their plans, and would adapt them more drastically if necessary. A typical comment came from one respondent who was hoping that their wedding and reception would be going ahead as scheduled but who would also 'accept simply a ceremony. It is nowhere near the wedding we planned but we now simply want to marry and affirm our love/move on with our lives'. Some had not yet abandoned their hopes of being able to celebrate with a larger number of family and friends but took the view that if restrictions continued they would simply marry with as many people present as was permitted. As one such respondent noted, 'as time has gone on it has made us re-evaluate the point of a wedding .... right now I just want to be able to call her my wife instead of worrying indefinitely about when we can host a big ceremony and what format it will take'.

Many of those who had had, or were planning, a small legal ceremony, were also intending to have a much larger celebration when conditions permitted. This second celebration was clearly seen as much more than a party. Some couples were planning to have something as close as possible to

\footnotetext{
${ }^{85}$ On this point it should be noted that the Home Office allowed a fiancé(e) or proposed civil partner whose wedding or civil partnership had been delayed due to Covid-19 to request an extension of leave: see WA56103, 16 June 2020.

${ }^{86}$ North Wales couple marry in their own flat in lockdown Zoom wedding', 30 May 2020, https://www.dailypost.co.uk/ news/north-wales-news/north-wales-couple-marry-flat-18332837; 'Coronavirus: Ellie Goulding surprises couple in online celebration after they are forced to postpone wedding’, 19 April 2020, https://inews.co.uk/news/uk/coronavirus-covid-19ellie-goulding-2543072 (both last accessed 17 March 2021).
} 
their original plans as a way of marking their first wedding anniversary. Others spoke of a blessing, a vow renewal with a registrar, or a celebrant-led ceremony. ${ }^{87}$ For some the second celebration was a reception; for others it was their 'wedding', a mark of the extent to which the term is now used to refer to the celebrations surrounding getting married, rather than the fact of getting married.

This brings us on to the large group who could not envisage marrying without their friends - and more particularly their families - being present. Respondents frequently mentioned that they wanted to ensure the attendance of a particular member of their family, often one who lived overseas or who was ill. The vulnerability of some family members posed a particular dilemma for this group, who were all too painfully aware that while attending a wedding brought its own risks, postponing might mean that their parents or grandparents were no longer alive to see them married. Those from large families commented that a limit of 30 did not even cover immediate family: one, who had originally planned a wedding for 380 , noted that her siblings and their partners comprised 42 guests. Cutting numbers was reported as causing upset with those family members who were no longer invited. And the necessity of complying with social distancing measures was seen as removing much of the joy from the occasion: as one respondent put it, '[a] wedding is a place of love, we want to be able to hug people and celebrate this properly'. As another reflected, being unable to participate in the usual rituals with loved ones had left them 'feeling lost and robbed of a major life experience'; such rituals were not simply a 'party', since '[i]n times of hardship and hurt, people look to our known traditions and rituals for certainty and hope for the future - without these ceremonies, people are left hopeless'.

The final group consisted of those whose responses focused more on the organisation of their wedding and the changes that they had made to the practical arrangements. To say that these respondents were focused on the wedding as an event in and of itself is not to suggest that they did not take getting married seriously, or to trivialise the importance that they attached to the wedding. ${ }^{88}$ These respondents emphasised the time and effort that had gone into planning the wedding and the financial costs of reorganising it. Many mentioned their 'special day' had been two or three years in the planning and they were understandably bitterly disappointed that all this had come to nothing. Flowers had been thrown away, flower-girls and pages had grown out of the outfits that had been bought for them, and items proudly displaying the intended date were a sad reminder of what might have been.

These responses raise important issues about the significance, scale, personalisation and expense of weddings today, which we explore elsewhere. ${ }^{89}$ For present purposes, our focus is on how they might help shape solutions for the future.

\section{Planning for the future}

As the findings of our study illustrate, a small proportion of couples planning to marry at any given time are particularly badly affected by any outright restriction on weddings because of the importance that they attach to marriage as a prerequisite to setting up home together or having children. In an era in which the vast majority of couples live together before they marry and around half of all children are born outside marriage, and at a time when public health considerations were paramount, it was perhaps

\footnotetext{
${ }^{87}$ In England and Wales, at the time of writing, humanist and independent celebrants cannot solemnise weddings. Many couples, however, opt for the highly personalised ceremonies that celebrants offer - usually, but not always, in addition to a couple's legally binding marriage ceremony. For an exploration of the work of independent celebrants, see S Pywell 'The day of their dreams: celebrant-led wedding ceremonies' (2020) Child and Family Law Quarterly 177.

${ }^{88}$ For commentary on the significance of the way in which marriages are conducted, see Leeds-Hurwitz, above n 14; CC Otnes and EH Pleck Cinderella Dreams: The Allure of the Lavish Wedding (Berkeley: University of California Press, 2003); M Kalmijn 'Marriage rituals as reinforcers of role transitions: an analysis of weddings in The Netherlands' (2004) 66 Journal of Marriage and Family 582; S Cretney 'Relationships: law content and form' in J Trowell and C Thorpe (eds) Re-Rooted Lives (Bristol: Jordans, 2007); Edge and Corrywright, above n 13; J Eekelaar 'Marriage: a modest proposal' (2013) Fam Law 83; J van Hooff Modern Couples? Continuity and Change in Heterosexual Relationships (Farnham: Ashgate, 2013).

${ }^{89}$ 'Postponing the day of your dreams: modern weddings and the impact of Covid-19' (in preparation).
} 
understandable that no conscious provision was made for this group. But the passionate pleas from some of our respondents underline the importance of ensuring that some provision is made.

Here it is worth noting that a number of jurisdictions did modify the requirements for a legally binding marriage to enable weddings to go ahead despite the lockdown. For those that already required relatively few formalities, this was a relatively simple matter. The US State of Colorado seems to have been the first, issuing an Executive Order on 26 March to enable marriage licences to be issued despite the closure of the offices from which they would normally be issued. ${ }^{90}$ This suspended the laws requiring at least one party to the prospective marriage to appear in person before a county clerk and recorder, and the in-person submission of proof of age and eligibility to marry, and encouraged officials 'to adopt guidance and publicly display such guidance online' as to what was required by way of application and evidence. It also suspended the usual restrictions that licences could only be issued during office hours as prescribed by law and, once issued, would only be valid for 35 days. The absence of any mention of how the wedding could be solemnised reflects the fact that Colorado recognises weddings that are self-solemnised, ${ }^{91}$ as well as allowing a wide range of officiants to conduct them. ${ }^{92}$ Couples are simply required to return the licence and accompanying certificate within 63 days of the wedding.

But even jurisdictions that did require a third person to conduct the ceremony made adaptations to how this could be done. On 12 April the United Arab Emirates - which had suspended marriages and imposed restrictions on movement - announced a new procedure for getting married that allowed all stages to be completed online. Couples would be able to log on to the website of the Ministry of Justice to submit the required evidence. Once their application to marry had been approved, they would be able to book an appointment with the Ministry of Justice, who would appoint an imam to conduct the ceremony. The ceremony - attended by witnesses - would be conducted via a video link. An electronic marriage certificate would then be submitted to the Sharia Court, which would verify the information, ratify the marriage contract, and send it to the couple's mobile phones. ${ }^{93}$ Just under a week later, the governor of New York, Andrew Cuomo, signed an order similarly authorising 'any issuance of a marriage license application, marriage license, or witnessing or solemnizing of the marriage ceremony, that is required under New York State law ...to be performed utilizing audio-video technology', subject to a number of conditions. ${ }^{94}$

Perhaps inspired by reports of such weddings, questions were asked in Parliament about whether it would be possible to allow couples to give notice remotely, ${ }^{95}$ or marry outside. Suggestions that the

\footnotetext{
${ }^{90}$ Executive Order D 2020014 Ordering the Temporary Suspension of Certain Requirements Preventing Issuance of Marriage Licenses due to the Presence of Covid-19, https:/www.colorado.gov/governor/sites/default/files/inline-files/D\% 202020\%20014\%20Marriage\%20Licenses_0.pdf. The original order was subsequently extended: see Executive Order D 2020 028, Extending Executive Order Ordering the Temporary Suspension of Certain Requirements Preventing Issuance of Marriage Licenses due to the Presence of Covid-19 in Colorado, https://www.colorado.gov/governor/sites/default/files/ inline-files/D\%202020\%20028\%20Extending\%20Marriage\%20Licenses_0.pdf (both last accessed 17 March 2021).

${ }^{91}$ Couples were advised that 'You and your intended spouse may solemnize your own marriage. Neither witnesses nor officiant are required for a valid self solemnization': ibid.

${ }^{92}$ Couples were advised that 'A marriage may be solemnized by an officiant who has been ordained or recognized by a religious denomination, a judge of a court, a retired judge, a court magistrate, a public official whose powers include solemnization of marriages, a Native American tribal official or a friend or relative who is ordained': ibid.

${ }^{93} \mathrm{See}$ https://gulfnews.com/uae/government/covid-19-uae-ministry-now-provides-online-services-to-hold-muslim-weddings-1.1586671705026.

${ }_{94}^{94}$ Executive Order 2020 No 202, Continuing Temporary Suspension and Modification of Laws Relating to the Disaster Emergency, https://www.governor.ny.gov/news/no-20220-continuing-temporary-suspension-and-modification-laws-relatingdisaster-emergency (last accessed 17 March 2021). These conditions limited such online weddings to couples who were physically present in the State of New York, required such couples to provide valid photo ID, and stipulated that 'the video conference must allow for direct interaction between the couple and the town or city clerk, the witness or the person to solemnize the marriage'. The couple were also required to ensure that the documentation was signed - by electronic means if necessary - by themselves, the person solemnising the wedding and the witness.

${ }^{95}$ Marriage: Video Conferencing: Written Question 52183, question asked by Rachael Maskell on 1 June 2020; answered by Chris Philp on 10 August 2020, https://www.parliament.uk/business/publications/written-questions-answers-statements/ written-question/Commons/2020-06-01/52183/ (last accessed 17 March 2021).
} 
government had failed to be 'creative by allowing vicars and registrars to marry people in private gardens ${ }^{96}$ rather underestimated the challenges involved in reorienting the law governing weddings around the person conducting the ceremony rather than the place of celebration. As the government repeatedly pointed out, any such changes would require altering the legislation governing weddings. ${ }^{97}$

That is not to say that such changes are not possible as part of a wider review of marriage law. Under the provisional proposals put forward by the Law Commission in its consultation paper, many of the problems we identified in the first section would disappear. It would be possible for notice to be given online or by post, reducing the risk of couples not being able to start the 28-day period in time for a ceremony immediately post-lockdown. Weddings could take place in the presence of just one registration officer, and would not be limited to taking place indoors, making it easier to comply with social distancing requirements. ${ }^{98}$

Of the Commission's specific proposals for powers that could be exercised in any future emergency, the responses to the survey clearly show that the possibility of extending the validity of the authority to marry beyond the existing 12 months ${ }^{99}$ would be welcome. The fact that this was not possible under the current law generated quite a number of complaints. As one put it, 'not extending people's wedding license is utterly ridiculous!' Quite apart from the financial implications, there was the time and annoyance of going through the process again, especially when, as one noted, all of their answers would be exactly the same as before.

The provisional proposal that weddings should, in any future emergency, be enabled to take place by video-link, would also have been welcomed by some couples. Of those who were asked if they would have considered this option, ${ }^{100} 8.5 \%$ responded in the affirmative. Most of these respondents were willing to consider any option that would enable them to get married legally: only $2 \%$ of the sample chose the video-link option alone. Viewed as a percentage of all couples getting married in England and Wales in any (normal) year, $8.5 \%$ would be over 20,000 couples, and even $2 \%$ would be around 5,000 . It is therefore an option that deserves serious consideration so that provision can be made for those who place primary importance on the legal fact - or necessity - of getting married.

Since it is unlikely that any couples had initially dreamed of marrying by Zoom, such a solution would do little for those who want a wedding as part of getting married. Nonetheless, it might help even in such cases. It was striking how many responses referred to items that had the date of the wedding on them, or to outfits that would never be worn because of the change of date. Enabling a wedding to go ahead by video-link would ensure that commemorative items did at least record the date of the legal wedding, even if other celebrations had to be postponed, and that outfits could be worn on the intended day.

An online wedding, of course, would not be the same as celebrating in person. But the responses to the survey suggest that the way in which the health regulations attempted to strike a balance between getting married as a legal event and a wedding as a social event failed to please anyone. For those couples who simply wanted to be married, having to wait until weddings were permitted to go ahead with 30 guests was particularly frustrating, especially since pubs, restaurants, and gyms had been able to open earlier. Allowing marriages to go ahead earlier, with the minimum number of persons required by law, would have mitigated some of their anger and upset. For those couples who wanted to celebrate with family and friends, the limit of 30 was also problematic. Hardly any of our respondents had been planning to marry with fewer than 30 guests, which meant that going ahead meant making difficult choices. One couple married in a register office with just their respective parents present on the basis that they could not choose just 30 people from their large families. A lower limit might actually have been better for this group too, by reducing the inevitable tensions with family and friends who found

\footnotetext{
${ }^{96}$ Hansard HL Deb, vol 804, col 241, 24 June 2020 (Baroness Warwick of Undercliffe).

${ }^{97}$ Ibid.

${ }^{98}$ Law Commission, above n 10 , para 11.57 .

${ }^{99}$ Ibid, para $11.82(1)$.

${ }^{100}$ This question was only asked of the 615 respondents who had been unable to marry during lockdown.
} 
themselves outside the top 30, and by differentiating more clearly between the legal ceremony and the celebrations still to come.

\section{Conclusion}

Covid-19 has shone a spotlight on the inconsistencies of the current law regulating weddings in England and Wales. Different types of weddings are subject to different preliminaries, different requirements as to who must be present, and different rules as to location, whether in terms of building, parish, or district. Such legal differences are compounded by differences in approach between different registration districts. Our findings show how in 2020 these differences - both legal and administrative - had the potential to determine whether a wedding could go ahead or not. At the same time, the complexities of the current law - which has developed over centuries - meant that changing any single aspect of it to facilitate weddings would have been problematic. This was not the case in other jurisdictions that either had fewer requirements or in which regulation was focused on the person conducting the ceremony rather than on where it was celebrated. Reform is clearly needed, but any such reform has to be holistic rather than piecemeal, and we hope that our findings will strengthen the case for making wedding law simpler and more flexible for the future.

The fact that for much of 2020 couples were either unable to marry, or unsure as to whether their planned wedding would go ahead, led many to reflect on just how important it was to them, whether for legal, religious, social, or emotional reasons. We hope that the clear evidence of the value that is placed on marriage demonstrates the need for some means of getting married to be available to couples, even - or perhaps especially - at the very worst of times. And we hope that all of those who responded to our survey have had, or at some point will have, a wonderful wedding day.

Cite this article: Probert R, Pywell S (2021). Love in the time of Covid-19: a case-study of the complex laws governing weddings. Legal Studies 41, 676-692. https://doi.org/10.1017/lst.2021.17 